WORKING PAPER NO. 1

Sept 1994

\title{
Overview on Forest Research in Africa
}

\author{
J.A. Sayer and J.R. Palmer
}

\section{Summary}

\begin{abstract}
Long and consultative planning processes have been undertaken to develop priorities for strategic forestry research in Africa. The results have contributed to the development of CIFOR's medium-term plan, so that there seems to be a good match between Africa's needs and CIFOR's intentions. The political divisions of Africa make it difficult to achieve critical mass in public sector institutions. There should be renewed attempts to establish group-country research so as to maximize the effectiveness of the small pool of trained research staff. Institutional strengthening and human resource development needs more attention nationally and from donor agencies. Forestry research institutions should recruit staff from a wider range of disciplines or should develop partnerships with a wider range of organizations. A much greater effort in economics and social science research is required to compensate for the frequent policy failures. CIFOR seeks active collaboration with appropriate organizations in Africa
\end{abstract}

CENTER FOR INTERNATIONAL FORESTRY RESEARCH

office address: Jalan Gunung Batu 5 Bogor 16001 Indonesia

mailing address: P.O.Box 6596, JKPWB Jakarta 10065 Indonesia

tel.: +62(251) 34-3652 fax: +62 (251) 32-6433

email: cifor@cgnet.com 


\section{The CGIAR System}

The Consultative Group on International Agricultural Research (CGIAR) is an informal association of 41 public and private sector donors that supports a network of sixteen international agricultural research centers, CIFOR being the newest of these centers. The Group was established in 1971. The CGIAR centers are part of a global agricultural research system which endeavor to apply international scientific capacity to solution of the problems of the world's disadvantaged people.

\section{CIFOR}

CIFOR was established under the CGIAR system in response to global concerns about the social, environmental and economic consequences of loss and degradation of forests. It operates through a series of highly decentralized partnerships with key institutions and/or individuals throughout the developing and industrialized worlds. The nature and duration of these partnerships are determined by the specific research problems being addressed. This research agenda is under constant review and is subject to change as the partners recognize new opportunities and problems. 


\title{
Overview on Forest Research in Africa ${ }^{1}$
}

\author{
J. A. Sayer ${ }^{2}$ and J. R. Palmer
}

\begin{abstract}
Summary
Long and consultative planning process have been undertaken to develop pririties for strategic forestry research in Africa. The results have contributed to the development of CIFOR's medium-term plan, so that there seems to be a good match between Africa's needs and CIFOR's intentions. The political divisions of Africa make it difficult to achieve critical mass in public sector institutions. There should be renewed attempts to establish group-country research so as to maximize the effectiveness of the small pool of trained research staff. Institutional strengthening and human resource development needs more attention nationally and from donor agencies. Forestry research institutions should recruit staff from a wider range of disciplines or should develop partnerships with a wider range of organizations. A much greater effort in economics and social science research is required to compensate for the frequent policy failures. CIFOR seeks active collabroation with appropriate organization in Africa.
\end{abstract}

\section{Introduction}

Ex Africa semper aliquid novi - This Latin proverb, there is always something new from Africa, is derived from an observation by Pliny. The first-century natural historian reported a common saying among Greeks, that Africa always offered something new. At the beginning of the second year of operation of CIFOR (Center for International Forestry Research), we also feel that much of global interest is happening in Africa. However, like Pliny, some of our information has been obtained at second hand. CIFOR is therefore pleased to be able to hear at first hand your concerns and to discuss with you how we may be able to assist.

\section{The non-forestry environment within which foresters must work}

Much of the information about Africa's needs for forestry-related research makes gloomy reading. Countries with relatively small but fast-growing and rapidly urbanizing human populations impose tremendous strains on public sector services. Attempts to recover from years of civil stress are often confounded by economic problems. African countries are grappling with structural adjustment programmes and trying to reconcile free market forces with social justice and a more equitable distribution of the benefits derived from natural resources. Africa south of the Sahara has 21 of the 31 poorest countries in the world. Forty out of 46 countries in the continent are relatively small, with human populations of less than 20 million. However, some of them have demographic growth rates near or above 3 per cent per year (Keita 1992). Numerous cities are expanding at 5-6 per cent per year but full time employment is growing much more slowly. Inevitably, therefore, governments are increasingly focused on urban problems. Even when policies are good and laws are just, governments are generally becoming less able to function effectively in rural areas, at least until economies improve substantially.

At the same time, in spite of urban drift and lower child mortality in urban areas, the population growth in rural areas is also above historical levels. Strains on renewable natural resources are occurring as several countries approach or have recently passed the agricultural frontier: the limit beyond which land cleared for agriculture cannot be farmed sustainably without

\footnotetext{
${ }^{1}$ Invited paper for the International Symposium Supporting Capacity Building in Forestry Research in Africa AAS/IFS in collaboration with FAO, 28 June - 1 July, 1994, Nairobi, Kenya.

2 Director General, Center for International Forestry Research (CIFOR), P.O.Box. 6596, JKPWB Jakarta 10065, Indonesia.

${ }^{3}$ Tropical Forestry Services Ltd., Oxford OX2 7AY, U.K.
} 
changes in farming technology. Traditionally, agricultural yields have been increased by expanding the area under cultivation, usually at the expense of forest and woodland, rather than by intensification of farming methods. Now, however, that is increasingly a measure of shortterm desperation, and in addition does little to support the burgeoning urban populations. Urban living and slow cooking are rarely compatible, so traditional diets are changing from root crops to fast-cooking, easily-stored grain. Urban markets tend to slimulatc grain imports, whose cost in turn may help to stimulate the development of intensive, high-input, high-output agriculture in peri-urban areas. There may be, as in southern Nigeria, great changes in land use around major cities but changes in production systems distant from cities are generally slow.

Economic reforms and structural adjustment programmes may encourage the development of export-oriented cash-cropping. Plantation estates may be created by excision from the permanent forest estate, as much because of fewer problems with land tenure and compensation as because of possibly less degraded soils than in old farm fallows. Small-scale farmers may convert wholly or partly to cash-cropping outgrower schemes if they are within transport distance of a nucleus estate. In either case, this results in pressure to shift staple and subsistence cropping to more marginal lands. If tenurial systems are strong and respected, the marginal lands may be improved, for example, with the aid of agroforestry techniques. The diversity of traditional land and tree tenurial systems in Africa, and the tension between tradition and tenure systems preferred by central government (but not always implemented efficiently or equitably), may lead to open access situations. With no one group feeling that investment is worthwhile in managing renewable natural resources, the best strategy for any individual or group is to exploit those resources to the maximum, if the national interest is ignored. In general, foresters have been slow to adjust their policies and practices to the complexity of the socio-economic, political and cultural contexts in which they must operate.

\section{The need for socio-economic input}

The natural resource systems in any one country may encompass sparsely populated semi-arid woodlands with nomadic pastoralists, rainforests and plantations under industrial production systems, and an infinite variety of medium and small scale farm-forestry enterprises in between.
The objectives of the human populations dependent on forests and woodlands likewise vary enormously, but forestry education, training and research usually emphasize the importance of tangible forest products. While this is understandable from the viewpoint of a national forest service or timber company, it is unlikely to represent the whole view of the majority of forestdependent people. This is not to underestimate the importance of tangible forest products in a continent where over 90 per cent of the recorded wood output is for fuel. Howcvcr, the frequent failure of woodlots designed entirely for fuelwood production shows the unsuitability of singleobjective forestry implanted without an understanding of the real needs and perceptions of producers and consumers. This was demonstrated almost three decades ago when the Ibadan fuelwood plantation in Nigeria was studied: it could not compete with firewood and charcoal carried on trucks operated mainly for other kinds of freight (King 1966). Similarly, projections of fuelwood needs in northern Nigeria and the requirements for fuelwood plantations were revised when market studies showed the competitiveness of fuel harvested far away in savanna woodlands and transported on top of petroleum fuel tankers (Thulin 1970).

\section{Any need for more research?}

Although the need for associated socio-economic research was appreciated in the 1930s (Stebbing 1937), African national forestry research has remained overwhelmingly silvicultural in approach. Agricultural research planners learned from the experiences of trying to cope with the terrible Sahelian droughts of the 1970s, that it was necessary for the human and political context to be understood for research to be relevant. Nevertheless, over a decade later, prognostications for agriculture were still mixed. Coulter's (1989) comments on the major Eastern and Southern Africa Agricultural Research Review by the World Bank in 1986-87 are relevant to forestry.

\footnotetext{
"Some of the discussions suggest that Africa has not undergone rapid productivity increases in agriculture because research has been inadequate or irrelevant. The contrary view is that there is a lot of scientific knowledge and technology already available, which is not being applied because it is not locally adapted or is not economically or socially acceptable in the prevailing political and economic conditions... there are elements of truth in all these assertions.
} 
A similar diversity of views was apparent during the various conceptualizations of the Tropical Forestry Action Plan (TFAP) in 1984-85 (WRI, World Bank and UNDP 1985). Research was initially confined to a rather minor role in TFAP. However, within two years the need was appreciated for research-based knowledge from which to develop new options for policies and practices. The first recommendation to be taken up after the 1987 Bellagio conference on TFAP was that for action on research (WRI 1987). The Rockefeller Foundation, together with UNDP, the World Bank and FAO, sponsored the International Task Force on Forestry Research (ITFFR) which reported at the 1988 Bellagio meeting (Holmes et al. 1988). The donors at the 1988 conference decided against the institutional options preferred by the ITFFR. However, the Consultative Group on International Agricultural Research (CGIAR) took up the challenge of providing institutional homes for international forestry and agroforestry research. The CGIAR absorbed the International Centre for Research in Agroforestry (ICRAF) in 1991, after ICRAF had been a non-associated center for some years, and began to create a new Center for International Forestry Research (CIFOR), also in 1991. CIFOR became operational in 1993.

There has been substantial input from Africa into these international discussions, based partly on a series of studies and meetings to enhance forestry research in the continent itself. We will not review here the many papers on national forestry research needs, opportunities and required resources developed as part of forestry sector reviews and national forestry action plans and programmes under the TFAP umbrella. We will concentrate instead on regional research.

\section{Strengthening national forestry research through group-country activities}

Here we step back to 1981, to the 17th World Congress of the International Union of Forestry Research Organizations (IUFRO). At that meeting in Kyoto (Japan), the World Bank and FAO proposed that "a small international forestry research secretariat should be funded to focus specifically on developing countries' research needs." Core funds from the World Bank and UNDP enabled IUFRO to create a Special Programme for Developing Countries (SPDC) in 1983. A major justification for emphasis on strengthening national forestry research services was given in the World Bank and FAO paper (1981):

"[.56.] Several strengths and weaknesses common to national forestry research institutions have been identified. Among these the strengths include the ability to relate research to development needs and the close involvement of local staff in planning and implementing research. The weaknesses include the lack of trained staff, funds and facilities, a vulnerability to arbitrary changes and a tendency to duplicate research completed or in progress elsewhere. "

[57.] Despite these and other weaknesses, almost all the organizations and individuals contacted during the course of this study have emphasized that the first priority should be to strengthen national forestry research institutions or create them where none exist. The various reasons cited can be briefly summarized. Firstly, biomass based energy research is likely to be of far greater economic significance in many developing countries than for most developed countries. Secondly, because of the wide diversity of climatic and ecological conditions and the large numbers of tree species used in developing countries, it is necessary that research be specific to site, particularly for species and provenance trials. Thirdly, research capacity built on a firm foundation at country level is likely to be more enduring than imported research. Fourthly, the alternative, (i.e. too great a dependence on overseas resources) fails to recognize that, for some of the newer research topics of interest to developing countries, appropriate techniques and experiences are not available in the developed world. The general thrust of the comments on institutional strategies made on the first draft of this paper by many agencies to whom it was circulated edvocatcd a massive shift in the physical location of research to the developing countries themselves with emphasis on appropriate operational scale accompanied by closer direction, stricter monitoring and a firmer commitment to research related to forestry for people."

Five regional workshops to plan group-country research were organized by IUFRO's SPDC for the "growing" side of forestry and three on the utilization side (Fugalli 1990). Four of these workshops were held in Afi-ica:

Nairobi 1986 (Carlson and Shea 1986); Nairobi 1987 (Iyamabo 1988); 
- $\quad$ Lilongwe 1988 (Burley and Cossalter 1988);

- $\quad$ Abidjan 1989 (Sales 1987).

The SPDC also organized two training courses on the management of forestry research, both held at Nairobi (Kenya), in 1986 (Temu et al. 1987) and 1989 (Iyamabo 1990).

In addition to the meetings organized by the SPDC, the World Bank studied the particular needs of Sahelian countries (Wencelius 1985) and West Africa generally (World Bank 1987). The Eastern and Southern Africa Agricultural Research Review conducted by the World Bank also contained an important forestry component (Burley et al. 1989). A forestry working group was established by the World Bank-coordinated Special Programme for African Agricultural Research (SPAAR) to review needs and opportunities (Cossalter 1987). A further major effort at regional research planning was funded by FINNIDA during 1990-92 (Salmi 1992, SADC 1992) for the SADC region.

A notable feature of the products from these studies and meetings has been a paradox. Orally, participants have usually agreed on the importance of socio-economic, political and institutional factors. However, proposed research programmes and projects have remained overwhelmingly biological and technological (see annex 1), at least until the beginning of the 1990s. The recent Zimbabwe National Policy Review for Forests and Trees (World Bank 1993) and the Malawi Agricultural Sector Memorandum (World Bank 1994), together with the review of dry zone forest management by Shepherd (1992), point out the crucial importance of improving policies for the management of renewable natural resources. These papers echo the now common emphasis on restoring the involvement of local communities and user groups in the management of renewable natural resources. They emphasise also the need for flexible implementation of practices at various administrative levels. These recent studies essentially reflect the findings of ISNAR.

We can generalize some of the problems related to agricultural research in sub-Saharan Africa as follows, keeping in mind that the situation differs from country to country:

- a large number of small national research systems with less than 100 researchers;

- research programs that do not reflect agricultural development priorities;

- obsolete organizational structures and management systems;
- difficulties in dealing with numerous agroecological zones and tribal customs and preferences;

- lack of infrastructure within most countries;

- the mediocre quality and low level of training, as well as the lack of experience of many researchers;

- insufficient level of funding and staffing to support professional researchers;

- inadequate information on research conducted in other countries and in international institutions, and a lack of linkages to them;

- the comparatively low level of university and private-sector research and a lack of effective linkages between this research on the one hand and national agricultural research systems and farmers on the other hand;

- $\quad$ inadequate research facilities;

- the lack of incentives and recognition for good research results;

- the large amount of time spent by researchers on non-research work.

"Much is expected of agricultural researchers. It is imperative that the highest levels of political leadership recognize the importance of agricultural research for economic, rural, and agricultural development. Each African country will have to find internal and external answers to their agricultural research problems. Donors must stand ready to assist in the search for the solutions and to support their applications" (Bonte-Friedheim 1990).

Problems which afflict national forestry research systems (NFRS) affect conservation organizations in much the same way. Participants at a UNESCO-sponsored meeting at Kinshasa (Zaire) in 1991 identified the weakness of training and research institutions in West and Central Africa as a critical problem (Sayer 1991).

The capacity to undertake traditional biological and technological research in Africa is more limited than in other developing continents. The capacity to undertake the critical policyrelated research is very limited. If the capacity is assessed only with reference to national (government) forestry research services (Iyamabo 1990), the position is indeed bleak. Responses to Iyamabo's questionnaire showed only 3 per cent socio-economists in NFRS: just 11 staff spread over 28 institutes. This in itself highlights two further weaknesses:

- peference for recruitment of government professional research staff from university 
faculties of forestry, and vice-versa; when there is expansion of curricula beyond traditional subjects, curricula for students are overloaded and frequently the time and resources allocated for field practicals decline as numbers and hours of lectures increase; a reluctance to recruit disciplinary specialists from outside a forestry background.

It is no surprise that much of the socio-economic and other policy research is carried out in nonforestry institutions, at universities, by social science institutes and by NGOs (Bradley and McNamara 1993). The difficulty then is to ensure that these organizations work on problems which are of high national priority and that the results feed into the appropriate levels of decisionmaking.

The small size of all but two of the NFRS surveyed by Iyamabo in 1988, compared with those in Latin America and Asia, obviously restricts their ability to tackle growing national problems of natural resources management. This restriction should stimulate both careful setting of priorities and a continual search for partners to share the research effort, nationally and regionally, to attain a critical mass of intellectual and practical effort. However, with a few notable exceptions (for example, the Gliricidia network run out of IITA, Ibadan; Attah-Krah and Sumberg 1987), regional research networks have been difftcult to start or maintain in African forestry. This was not the case when EAAFRO was in existence. IUFRO's SPDC had expected to build on the memory of EAAFRO's successes, through research which was expected to emanate from the regional planning workshops in the second half of the 1980s. However, EAAFRO had many built-in advantages, with highly experienced staff who mainly shared a common educational, managerial and research background and the same working language. Moreover, the civil administrative structure within which EAAFRO operated was essentially similar in the participating countries.

The group-country projects which emerged from the SPDC regional workshops had a more difficult start in life, in countries with far fewer resources of staff or cash or research institutions. The French government trust-funded an initial project (GCP/RAF/234/FRA) in the CILSS countries for the development of the genetic resources of multi-purpose trees. FAO executed the project in 14 countries of the Sudano-Sahelian zone. A similar exercise was proposed for the IGADD group of countries but has not yet come to fruition. Bilateral support from Germany and the
Netherlands has enabled follow-on projects in some of the CILSS countries. The experience gained through this recent regional cooperation, plus perceptions of the advantages obtained by collaboration in the Forestry Research Support Programme for Asia and the Pacific (FORSPA), has led to interest in the creation of a similar approach for Africa (FORSPAf). An informal workshop to explore the possibilities was convened by FAO in December 1993 at Ouagadougou (Burkina Faso); Jeff Odera attended as member of the Board of Trustees of CIFOR.

This is indeed an encouraging situation, especially after a period when regional projects had great difficulty in moving from concept to operation. A follow-up to the successful West African Hardwoods Improvement Project (Howland and Bowen 1977) was tried several times. IUCN made extensive preparations for a 7countries project on conservation and forest management in West and central Africa. Neither of these efforts was fruitful, although they appeared to fulfill most of the requirements for successful research networks (Burley 1989; Plucknett, Smith and Ozgediz 1990). The review of networks conducted by FAO (Kato 1992) showed how delicate is the line between success and failure in regional research cooperation.

There may be more chance of success with forestry research networks associated with the predominantly agricultural francophone Conference des responsables de recherche agronomique africains (CORAF), headquartered in Senegal. CORAF has been an exponent of networks in which each participating institution takes a lead for one aspect of thematic research, thus providing both carrot and stick to keep the donkey of research moving forward. CILSS and SADC are also umbrellas for non-forestry regional collaboration. All three organizations may be able to provide the continuity of support and administrative and technical back-up which a purely forestry initiative could find difficult to create and maintain.

\section{Institutional strengthening of forestry research capacity}

Wihin African national forestry research services, KEFRI in Kenya and FRIN in Nigeria were exceptional in Iyamabo's 1988 survey, with 81 and 69 research staff respectively. Excluding these two, the average number of professional staff among 28 NFRS was 8 , and indeed 11 of the 28 NFRS had 5 or fewer research staff. Iyamabo (1990) found NFRS staffing to average 25 per cent 
silviculturists, 15 per cent forest products specialists, 15 per cent soil scientists and ecologists, 11 per cent tree breeders. Other categories averaged less than 10 per cent. With such small absolute numbers of staff in most NFRS, generalized recommendations about changes in the proportion of staffing would be meaningless.

It was awareness of this numerical weakness that led IUFRO's SPDC and SADC to propose much greater regional research efforts, so as to maximize the effectiveness of the limited pool of trained forestry research staff. Unfortunately, IUFRO's SPDC lacked the financial-resources to promote regionally-integrated research, and FINNIDA's expected phase 2 support for SADC forestry research was affected by the decline of the Finnish economy. Experience in Central America, another region with several small countries but common problems, is that regionally-coordinated research can be very effective compared with small and scattered national efforts. However, the cash cost is still considerable and the regional coordinators need to have, or to develop, exceptional qualities of leadership. A parent or umbrella organization which already has experience of group-country coordination is obviously an advantage, as noted in the paragraphs above.

Over half the African NFRS are within national forestry services or from departments under line ministries. Less than a quarter of African NFRS are independent or semiautonomous institutions (Iyamabo 1990). As in other continents, there are explorations towards greater autonomy, especially towards freedom from government restrictions on funds, salary levels and career structures. However, although government salaries may be low and operating funds both scarce and unpredictable in timing, a switch to contract-funded autonomy brings other problems. The identification and cultivation of clients becomes obligatory, and major efforts must be devoted to the preparation and marketing of grant proposals. By no means all research staff who can survive in a line ministry NFRS are able to adapt to the more commercial world of an institute dependent on grantsmanship. The need for commercial survival in countries where customers are not used to paying for research may lead to a focus on short-term problem-solving to the detriment of longer-term research for generalizable results. Exceptional leadership is required during a transition yet, just as management training and commercial experience are in short supply, so is training in leadership for agriculture and forestry research (Nickel 1989). The insufficiency of training in management and leadership for forestry research was readily acknowledged during the two courses in East Africa (Temu et al. 1987, Iyamabo 1990).

Recognizing the traditional but well-known defects of government-based forestry research, yet still not equipped to break away entirely and rely on grant funding, organizations such as FRIN in Nigeria have explored other options to enhance staff effectiveness and satisfaction (Kio 1992). A policy of enrolling most professional-grade staff for further academic qualifications at local universities can bring several kinds of benefits. Higher degrees may be associated with higher points on a salary scale, as well as greater social and professional status. Work which is prescribed in a national or regional research programme becomes more personally mcaningful and stimulating. Opportunities for inter-disciplinary contacts and learning may be much enhanced. Additional operating funds may be secured through grants open to universities which are not available to government institutions. Practical and political problems of working with NGOs may be much reduced, with the universities providing neutral ground for contact and discussion.

Greater freedom of staff movement between NFRS and universities may contribute to greater job satisfaction and less academic poaching, although this is a recurrent problem where universities expand faster than their out-turn of experienced graduates. Provided that staff remain in-country or in-region, the national authorities may take a reasonably relaxed long view of staff interchange and lateral career moves, since the country or region does not completely lose the expensively-trained brainpower.

African NFRS might wish to explore incentive systems (Abdul Razak 1992) such as promotion points for different kinds of activity (including various classes of publication or public dissemination of research, extension work, or training delivered to clients). Even small prizes can have a galvanic effect. Foresters from North America frequently comment on the lack of attention to prizes and other personal incentives in Europe and the palaeotropics.

\section{Technical collaboration and cooperation}

Almost 80 per cent of the 28 African NFRS surveyed by lyamabo (1990) were dependent to some extent on technical assistance from multilateral or bilateral agencies. In contrast, only 
7 per cent captured resources through competitive grant funding, and most of that was in Tanzania. A major programme is thus indicated for those who wish to move more towards autonomy and contract funding, to teach the preparation and marketing of proposals for research projects.

Improvement of research efficiency and effectiveness through increased inter-institutional collaboration should not, in principle, be so difficult. Eighty-six per cent of African NFRS reported to Iyamabo that they collaborated with other research institutes, 45 per cent had links with international centres (including International Agricultural Research Centers, IARCs) and 45 per cent had national collaborations. Collaboration has been mostly in relation to joint field trials (especially tree improvement and agroforestry), seed supply, information exchange, and workshops, seminars and conferences (Iyamabo 1990).

During the middle 1960s, there was some enthusiasm for twinning of institutions in developing countries with those in the industrialized world. Such links were especially promoted between nascent and older universities. However, they have proved hard to sustain. Strains have included the decline in university core funding in the industrialized countries and sometimes politically-motivated expansion of student numbers in developing countries far beyond the corresponding resources for teaching. Although individual faculties are often keen to establish or maintain inter-regional links, the high administrative costs of twinning need to be spread across whole institutions; they are too much for individual departments. The promotion of twinning was one of the six points in the action programme developed by Fugalli in 1984 for IUFRO's SPDC, but was the only one for which no funds could be obtained from donor agencies (Fugalli 1990). Inter-country links covering many academic institutions (for example, MEXUS which links Mexican and U.S. universities) may have a better chance of survival than smaller programmes, again because the high administrative costs can be more spread out.

\section{CIFOR and Africa}

As wc mentioned at the beginning, there has been substantial input from Africa to the establishment phase of ClFOR. There were notable contributions from Africa to ITFFR in 1988 (by lyamabo, El Lakany, and Awori). Members of the ACIAR/CIFOR establishment team attended a CORAF meeting at Dakar in March 1992 and a
SADC seminar during the regional research planning exercise also in early 1992. The ACIAR/CIFOR establishment team leader and some CIFOR Board members attended the IFPRIICRAF-CIFOR forest policy research seminar in Nairobi in November-December 1992. Jeff Odera (KEFRI) and El Hadji Sène (Sènègal/FAO) are members of CIFOR's inaugural Board of Trustees. CIFOR's medium-term plan 1994-1998 (draft 10, September 1993) has been widely distributed to interested parties in Africa. During the preparation of earlier drafts of the medium-term plan, several African organizations were identified as potential partners for strategic research.

CIFOR's most recent major contact with Africa was the workshop on socio-economic research on miombo woodland management in southern Africa, held in Zimbabwe during 14-17 March this year. Participants expressed most interest in collaboration to aid the synthesis of existing scattered knowledge, experience and practices in the region. Cooperation was also contemplated in the identification and development of new or improved products from miombo woodlands and their markets.

In this section, we will examine how CIFOR's medium-term plan fits with overall African priorities for forestry research as suggested by Iyamabo and El Lakany (1988), using the eight headings of those authors:

\section{1 - Database of available research results}

The intention of Iyamabo and El Lakany was to aid implementation and use of the global knowledge base, avoid duplication, identify gaps, and specify research to augment incomplete information. ClFOR will not be duplicating existing information systems which operate nationally, nor subject-matter newsletters which circulate through networks. Formally published information at the international journal level will usually reach the $\mathrm{CAB}$ International abstracting services and so will be disseminated through original -journals and books and via the various abstract formats (paper journals, diskette, on-line computers, and CD-ROM). CIFOR will encourage the use of such information systems and may help its major partners to acquire forestry-related CD-ROM if they are not already in use.

Developing a proposal conceived at 1UFRO's SPDC, CIFOR has proposed a (Tropical) Tree Growth Potential Information System (TROPIS). TROPIS was intended to facilitate joint and combined access to the major databases on the growth and yield of tropical trees in trials and 
plantations. Databases to be linked included TREDAT (Australia), MPTSys (Winrock International/ US-AID/MPTS Secretariat, South East Asia), MIRA (CATIE, Central America), MPT database (ICRAF, Kenya) and Sistem+ (Oxford Forestry Institute, U.K.).

It was considered impracticable to develop and maintain "mega" databases to hold large quantities of tropically-relevant raw or summarised research results. However, there is considerable demand for information about which research projects are currently in progress and which have been completed recently. The European Tropical Forest Research Network (ETFRN) is developing a "front end" system, EASDSS, to the European Commission's agricultural research database AGREP. It was anticipated that CIFOR's Forestry Research Network Information System (FORNIS) would aid the development and general application of AGREP to regions outside Europe. FORNIS would also have incorporated material gathered by IUFRO's SPDC, plus other information obtained during the establishment of CIFOR, about forestry research institutions globally and their projects, donor policies and procedures, editorial requirements of forestryrelated journals, etc. TROPIS work now falls under CIFOR's Programme 2 while FORNIS comes under Programme 5.

\section{2 - Biology of tree species}

The ACIAR/CIFOR establishment team considered that CIFOR should be orientated towards the solution of geographically widespread and socio-economically important problems through strategic research. CIFOR should not be species-orientated, since at least 32 groups or networks have been identified which are focused on individual species, genera or groups of tropical tree species. However, because so much remains to be learned about the reproductive biology of tropical tree species, Activity 2.5 of CIFOR's Programme 2 deals with general problems of reproductive biology and genetics. Topics will include:

- interactions between type of tree reproductive biology, including phenology, pollination biology and mating system, fruit biology, dispersal and seed biology on the genetic structure of wild tree populations;

- $\quad$ effect of forest fragmentation, selective logging and natural disturbance on the genetic structure of tree species populations;

-- patterns of genetic variation within a taxon, studied by combinations of biochemical, cytological and molecular marker techniques, and leading to improved sampling of native populations;

- genetic structures, mating systems, gene flows in natural forests;

- reproductive biology, phenology of trees with irregular flowering and fruiting, management of pollinator and disperser populations;

- cffcctive population sizes needed to maintain evolutionary flcxibility;

- $\quad$ effects of differcntial harvesting on genetic structure and demography.

There is thus a good correspondence between CIFOR's medium-term plan and Iyamabo \& El Lakany's suggestion for research on indigenous and exotic species, which included "flowering and seed production, reproductive biology, growth patterns, phenology, and basic chemical components".

\section{3 - Human resources development}

Iyamabo and El Lakany stressed post-graduate training to M.Sc. and Ph.D. levels, and skills development for research technicians. While some of the larger IARCs support academic training as such, CIFOR's resources are too limited. Instead, we have a policy that human resources development will be principally through the skills to be acquired by close association with our research activities. Activity 5.1 of CIFOR's Programme 5 deals with human resource development:

The primary mechanism by which CIFOR will strengthen forestry research capacity will be through exemplary research partnerships. Initially, these will be with a limited number of forestry research organizations which already have a comparative advantage in CIFOR's priority research areas. In parallel, CIFOR will need to provide guidance and information to a broader network of forestry research organizations and to begin the process of contributing to their institutional development.

CIFOR will provide assistance to the strategic planning and human resource development of research institutions in developing countries. Workshops and seminars linked to CIFOR research will be an important mechanism for this assistance. CIFOR will not initially have "free-standing" training activities. However, it will take every opportunity to contribute to the training needs of its stakeholders through contributions to and association with training 
activities conducted by others, through production of texts and electronic teaching materials, internships and in general by conducting its research and communication work in an open and participatory manner.

4 - Forestry in land use, including agroforestry. This is a vast area for a single priority. ICRAF is, of course, the lead institution in the CGIAR for agroforestry. Iyamabo and El Lakany mentioned the role of trees in soil improvement, sustainable agricultural production, and in protection of watersheds. These topics are not addressed as such in ClFOR's medium-term plan, but Programme 3 deals with restoration of degraded lands. Relevant activities include:

CIFOR Activity 3.1 - Non-industrial techniques for reforestation of degraded lands. Studies may include:

bio-economics of communities in South East Asia (Indonesia and Philippines) which have developed rotational fallow farming systems in fire disclimax Imperata grasslands; restoration of Chromolaena-infested agricultural fallows in West Africa;

- consolidation and summarization of the substantial but under-used literature on recovery of Imperata and Saccharum grasslands, Lantana scrublands and other areas invaded by persistent weeds.

CIFOR Activity 3.2 - Matching tree species/genotype to bio-physical site conditions and management systems. Studies may include:

\section{Genotype-Site matching}

- development of ideotype profiles, (sets of characteristics of the ideal tree to fulfill defined objectives) for plantations, e.g. trees for erosion control, for house poles, for sawn wood;

genotype-site matching for rehabilitation of degraded/depleted soils, acidic, salinized and sodic soils, waterlogged and weed-infested sites;

management techniques to enhance the efficiency of soil microbe - tree genotype interactions and to minimise risks of loss from pests and pathogens.

Eco-Physiology

relation of morphological and behavioural variations to eco-physiological adaptations; efficiency of use of light, water and nutrients, including irrigation and applied fertilizers (mainly to aid the development of predictive models);

adaptations to extreme environmental stresses, including effects of: pollution, waterlogging, wind, fire, low temperature and high solar radiation, low light, aridity, saline and sodic soils.

\section{Microbial Relations}

identification of beneficial and detrimental microbes and their genetic variation;

interactions between tree genotypes and microbe genotypes and methods for enhancing symbioses, including plant nutrition and water uptake;

rhizosphere dynamics, including synergy between beneficial microbes;

population dynamics and ecology of microbes, especially in relation to disturbance of soil or vegetation;

biological nitrogen fixation (BNF): including assessment of BNF over long periods; selection of tree genotypes for high BNF; and identification of high-yielding Rhizobium strains.

\section{Growth and Yield Models}

mechanisms to allow transfer of data between existing major databases on tropical tree growth, to standardize or harmonize tree and stand assessment methods, to allow singlemenu access to the major databases. Work has been started on a Tree Growth Potential Information System (TROPIS); this has been transferred to CIFOR Programme 2.

incorporation into growth and yield models of effects of weeding, fertilizing, spacing, thinning, pruning, coppicing and pollarding, as well as collection of fodder, flowers and fruit, and the detrimental effects of fire and collection of leaf litter;

eco-physiological process models to predict tree growth and yield and their validation against long-term measurements of tagged trees in permanent experimental and yield plots.

5 - Problems of dry tropics in areas with less than $250 \mathrm{~mm}$ of rainfall a year.

Iyamabo and El Lakany proposed research on:

management for increased production and sustained use of natural savanna woodland; 
climate and meteorology, soil moisture, temperature, relative humidity, etc.;

establishment and promotion of early growth of plantations;

selection of species and provenance evaluation;

problems of irrigated plantations, high salt content, flooding, and plant water requirements.

CIFOR's activity 2.4 in Programme 2 directly addresses the sustainable management of dry-zone woodlands. Studies include:

refinement of land zoning systems to identify areas of high potential for sustainable agriculture and forestry;

bio-economics of the diverse products of dry forest and systems for enhancing value of these products locally (including reduction in wastage during processing);

rigorous assessment of existing knowledge about the ecology, silviculture and management (especially fire management) of miombo and related woodlands.

Possible collaboration on research for enhanced management of miombo woodlands, resulting from the recent workshop in Zimbabwe. is mentioned in paragraph above.

Other aspects are covered either by ClFOR Activity 3.2 in Programme 3, as described above, or they have been deemed to be more appropriate for local, adaptive and applied research because problems are species-specific or particular to individual sites.

\section{6 - Policy research including socio-economic research}

CIFOR's Programme 1 is entirely concerned with policy development. Participants in the IFPRIICRAF-CIFOR regional workshop at Nairobi in November-December 1992 were invited to help set priorities for CGIAR research on forestry and agroforestry policies. The participants provided a useful list of 17 topics, however without priorities, and it will require further discussion to determine how they fit with CIFOR's Programme 1. Some topics fit better with other CIFOR Programmes. For example, "development of improved low cost, less damaging, and less wasteful timber extraction methods ..." matches CIFOR's activity 2.1 Lowimpact harvesting/management, while "issues and methods related to conservation of biodiversity" matches ClFOR's activity 2.2 Management of biodiversity and diverse products.
7 - Conservation of tropical ecosystems and their genetic diversity

CIFOR's activities 2.2 and 2.5 cover this field, as mentioned above.

\section{8 - Genetic improvement and biotechnology}

The CGIAR is still developing a rational division of labour in this field between CIFOR, ICRAF and IPGRI (International Plant Genetic Resources Institute, which incidentally has just had its mandate expanded to include animal germplasm). CIFOR sees its role in relation to policy aspects of genetics and germplasm, and is thus involved in the 1995 FAO Commission on Plant Genetic Resources. CIFOR will concentrate on the methodological aspects of tree improvement and will avoid overlap with the many groups dealing with tree selection and breeding of particular tropical species and genera. CIFOR's involvement in biotechnology will be limited, because there are many other competent groups already engaged in this field.

I hope it will be obvious that there is strong agreement between the priorities for research which were identified for Africa by Iyamabo and El Lakany in 1988 and the main areas of' CIFOR's medium-term plan. This should not be surprising, because the ACIAR/CIFOR establishment team involved about I200 people in consultalions leading to development of the initial strategy and medium-term plan. In addition, numerous sector review papers (including TFAP) and SPDC documents were studied. We have tried to ensure that the CIFOR plan reflects the needs of developing countries as those countries themselves perceive the problems and requirements for strategic research.

\section{Issues relating to the future of research on African forests which require further examination}

Major reviews, such as those carried out under TFAP, National Conservation Strategies and National Environmental Action Plans, have consistently indicated that Africa's forestry research is inadequate to meet the challenges of a human population doubling between 1990 and 2010. The research effort is also disproportionately small to cope with the desertification which threatens or overwhelms over half the sub-Saharan land area. Many problems are country- or location-specific, and are therefore outside CIFOR's mandate. Many other problems are common across ecosystems and 
social groups found in several countries and should be amenable to resolution or mitigation through strategic, group-country research. Like several other organizations, CIFOR is impressed by the effectiveness of EAAFRO during its 27 years of regional research until 1977. Like them, we are puzzled by the difficulty of developing and sustaining regional research networks subsequently. So many facts argue in favour of group-country forestry research, yet there have been few recent successes.

CIFOR considers that the institutional aspects of forestry research are themselves researchable topics. We look forward to constructive relationships with African organizations to help develop local capacity to deal with local problems.
We may be useful in facilitating transfer of regional experience from, for example, MADELENA in Central America and FORSPA in Asia, and in strengthening the forestry-related work of CILSS, CORAF and SADC, plus the incipient FORSPAf.

Institutional strengthening and human resource development should run in parallel with clarification of the priorities suggested by Iyamabo and El Lakany (1988) and IFPRI (1993), and the consequent forging of research-based links between CIFOR and African organizations. We in CIFOR look forward to developing further our research planning and support in Africa, firmly based on the priorities (and gaps) which will be identified or highlighted during this symposium.

\section{References}

Abdul Razak bin Ali., 1992: Strengthening of national forestry research: Malaysia. Paper number 6, expert meeting on forestry research. Rome, 12-14 October 1992. Rome, Italy; Food and Agriculture Organization of the United Nations, Forestry Department. 1 lp.

Attah-krah, A.N.; Sumberg, J.E., 1987: Studies with Gliricidia sepium for crop-livestock production systems in West Africa. In Withington, D.; Glover, N.; Brewbaker, J.L. (editors) Gliricidia sepium (Jacq.) Waip.: management and improvement. Proceedings of a workshop held at CATIE, Turrialba, Costa Rica, June 1987. Waimanalo, Hawaii: Nitrogen Fixing Tree Association Special Publication 87-0 1. p3 1-43.

Awori, A., 1988: Priority issues on forestry research: an African NGO perspective.Background paper number 6. International Task Force on Forestry Research. New York; The Rockefeller Foundation.

Bonte-Friedheim, C., 1990: Small pool of scientists just one of many problems plaguing African research. ISNAR Newsletter number 13, April. The Hague, Netherlands; International Service for National Agricultural Research (ISNAR). p3.

Bradley, P.N. and McNamara, K. ,1993: Living with trees: policies for foresty management in Zimbabwe. Technical Paper number 2 10. Washington, D.C.; World Bank. 329p.

Burley, J., 1989: Options for forestry research networking.In Lundgren, AL. (editor) The management of large-scale forestry research programs and projects. Proceedings of a meeting of IUFRO Subject Group S6.06 Management of forestry research, April 17-19, 1989, Alice Holt Lodge, Farnham, England. General Technical Report number NE- 130. Broomall, Pennsylvania; U.S. Forest Service Northeastern Forest Experiment Station. p 185- 199.

Burley, J. et. al, 1989: Forestry research in Eastern and Southern Africa: based on a contribution to the World Bank's Sub-Saharan Africa Agricultural Research Review, 1986. Tropical Forestry Paper number 19. Oxford, U.K.; Oxford Forestry Institute. 58p + 27 annexes separately paginated.

Burley, J.; Cossalter, C.G., 1988: Report on tree improvement. Background paper for the IUFRO regional planning workshop for East and Southern Africa, Lilongwe, Mala-i, 19-28 October 1988. Vienna, Austria; International Union of Forestry Research Organizations, Special Programme for Developing Countries. $42 p+8$ annexes separately paginated.

Carlson, L. W.; Shea, K.R. ,1986: Increasing productivity of multipurpose lands. Proceedings of the IUFRO research planning workshop for Africa (Sahelian and North Sudanian zones), Nairobi, Kenya, 9-15 January 1986. Hull, Canada; Canadian Forest Service.

Cossalter, C.G., 1987: Overview of current forestry research situation and future trends in Africa south of the Sahara. SPAAR meeting, Paris, France, 9-10 September 1987. Rome, Italy; Food and Agriculture Organization of the United Nations, Forestry Department. 
Coulter, J.K., 1989: $\quad$ Research for agricultural development in sub-Saharan Africa. Seventh Ralph Melville Memorial Lecture - December 1989. Tropical Agriculture Association (UK) Newsletter 9 (4): $1-11$.

Fugalli, O., 1990: IUFRO special programme for developing countries, July 1983 - December 1990. Report for the 19th IUFRO. World Congress, Montreal, Canada, August 1990. Vienna, Austria; International Union of Forestry Research Organizations, Special Programme for Developing Countries. Typescript. 13p.

Holmes, G.D. et. al., 1988: A global research strategy for tropical forestry. Report of an international task force on forestry research. New York; The Rockefeller Foundation, the United Nations Development Programme, the World Bank and the Food and Agriculture Organization of the United Nations. 88p.

Howland, P. and Bowen, M.R., 1977: West African hardwood improvement project research report 197 I-1977. Triplochiton scleroxylon K. Schum. and other West African tropical hardwoods. Lagos, Nigeria; Federal Department of Forestry Research. 109p + 154p appendix.

IFPRI , 1993: Summary of main workshop areas of discussion and conclusions. IFPRI-ICRAF-CIFOR regional workshop on priorities for forestry and agroforestry policy research, ICRAF, Nairobi, 30 November - 4 December 1992. Washington, D.C.; International Food Policy Research Institute. $15 \mathrm{p}$.

lyamabo, D.E., 1990: Managemcnt of forestry research in Africa. Proceedings of a IUFRO workshop held in Nairobi, Kenya: 21-30 June, 1989. Nairobi, Kenya; international Union of Forestry Research Organizations, Special Programme for Africa. ISBN 978-30333-6-0. $11+343 \mathrm{p}$.

Iyamabo, D.E., Cossalter, C.; Iyamabo, D.E.; Krugman, S.L.; Fugalli, 0. (undated, but 1988) Tree improvement and silvo-pastoral management in Sahelian and North Sudanian Africa: problems, needs and research proposals. Vienna, Austria; International Union of Forestry Research Organizations, Special Programme for Developing Countries. 196p.

Iyamabo, D.E.; El Lakany, M.H., 1988: Forestry research in Africa: problems, priorities and needs. Background paper number 3. International Task Force on Forestry Research. New York; The Rockefeller Foundation. 35p + 16p annex.

Kato, M., 1992: Research support networks: review of FAO experience with research networks. Paper number 16, expert meeting on forestry research. Rome, 12- 14 October 1992. Rome, Italy; Food and Agriculture Organization of the United Nations, Forestry Department. 13 + 3p.

Keita, J.D., 1992: Research support networks: sub-Saharan Africa. Paper number 13, expert meeting on forestry research. Rome, 12-14 October 1992. Rome, Italy; Food and Agriculture Organization of the United Nations, Forestry Department. 12p.

King, K.F.S., 1966: An economic analysis of the Ibadan fuel plantation. Nigerian Forestry Information Bulletin (new series) number 17, 13p.

Kio, P.R.O., 1992: Training and development of scientists for forestry research: Nigeria.Paper number 9 , expert meeting on forestry research. Rome, 12-14 October 1992. Rome, Italy; Food and Agriculture Organization of the United Nations, Forestry Department, 9p.

Nickel, J.L., 1989: Research management for development: open letter to a new agricultural research director. Libros y Materiales Educationales/IICA number 89. San José, Costa Rica; Instituto Interamericano de Cooperacidn para la Agricultura. ISBN 929039154-5. 12 + 129p.

Plucknett, D.L.; Smith, N.J.H. and Ozgediz, S. , 1990: Networking in intcrnutionul agricultural research. Ithaca, New York; Cornell University Press. ISBN O-80 14-2384-8. 224p.

SADC, 1992: Forestry research plan for the SADC region. SADC project AAA.5.23 improvement and strengthening of forestry and forest products research institutions in the SADC region: Lilongwe, Malawi; SADC Forestry Sector Technical Coordination Unit. 126p.

Sales, C. , 1987: Enquête sur les besoins de recherche en technologie du bois pour le continent africain; (projet). Paris, France; Centre Technique Forestier Tropical, IUFRO Project Group P5.01 Properties and utilization of tropical woods. 28p.

Salmi, J. , 1992: Research support networks: research support for the SADC region. Paper number 20, expert meeting on forestry research. Rome, 12-I 4 October 1992. Rome, Italy; Food and Agriculture Organization of the United Nations, Forestry Department. $12+$ lop.

Sayer, J.A., 1991: African forest conservation meeting. IUCN Forest Conservation Programme Newsletter number 10, June. Gland, Switzerland; 'I'hc World Conservation Union (IUCN). p 10. 
Shepherd, G.,1990: Managing Africa's tropical dry forests: a review of indigenous methods. ODI agricultural occasional paper number 14. London, U.K.; Overseas Development Institute. 117p.

Stebbing, E.P. ,1937: The forests of West Africa. A study of modern conditions. London, U.K.; W. \& R. Chambers, Ltd. 245p.

Temu, A.B., et. al., 1987: Forestry research management. Proceedings of the IUFRO training course on forest research management for anglophone Africa, Nairobi, Kenya, 13-29 October 1986. Helsinki, Finland; National Board of Vocational Education, Forestry Training Programme (FTP). $166 \mathrm{p}$.

Thulin, S., 1970: Wood requirements in the savanna region of Nigeria. Technical report number 1. Ibadan, Nigeria; UNDP/FAO forestry project FOR:SF/NIR 16.

Wencelius, F. , 1985: Forestry research in the Sahel countries. Centre national du machinisme agricole, du génie rural, des eaux et des foréts, France. Washington, D.C.; World Bank. 91 p.

World Bank, 1987: West Africa Agricultural Research Review, 1985-86. Washington, D.C.; World Bank West Africa Projects Department. 413p.

World Bank, 1993: Zimbabwe national policy reviews for forest and trees. $\quad$ Report number 11776-ZIM. Washington, D.C.; World Bank Southern Africa Department, Agriculture Operations Division. $135 \mathrm{p}$.

World Bank, 1994: Malawi agricultural sector memorandum: strategy options in the 1990s. Report number 12805-MAI. Washington, D.C.; World Bank Southern Africa Department, Agriculture Operations Division. 3 volumes.

World Bank and FAO, 1981: Forestry research needs in developing countries - time for a reappraisal? Special paper for the 17th IUFRO World Congress, Kyoto, Japan. Washington, D.C.; World Bank, and Rome, Italy; Food and Agriculture Organization of the United Nations.

World Resources Institute; World Bank; UNDP, 1985:Tropical forests: a call for action. Part I: the plan. Report of an international task force convened by the World Resources Institute, The World Bank and the United Nations Development Programme. Washington, D.C.; World Resources Institute. $49 \mathrm{p}$.

World Resources Institute, 1987: Statements and background documents from the Bellagio Strategy Meeting on Tropical Forests. Washington, D.C.; World Resources Institute. 


\section{Acronyms}

AAS African Academy of Sciences, Kenya

ACIAR Australian Centre for International Agricultural Research, Australia

AGREP Agricultural Research Projects in the European Communities, permanent inventory database (CEC), Belgium

CATIE Centro Agronomic Tropical de Investigacion y Ensenanza, Costa Rica

CD-ROM compact disk - read only memory

CGIAR Consultative Group on International Agricultural Rcscarch, Washington, D.C., USA

CIFOR Center for International Forestry Research (CGIAR), Indonesia

CILSS Comité permanent inter-États de lutte contre la sécheresse dans le Sahel, Burkina Faso

CORAF Conference des responsables de (la) recherche agronomique africains, Senegal

EAAFRO East African Agriculture and Forestry Research Organisation (extinguished in 1977) Kenya

EASDSS ETFRN/AGREP-Supplementary-Data-Service-System (ETFRN), Federal Republic of Germany

ETFRN European Tropical Forest Research Network, Federal Republic of Germany

FINNIDA Finnish International Development Agency, Finland

FORNIS Forest Research Networks Information System (CIFOR), Indonesia

FORSPA Forestry Research Support Programme for Asia and the Pacific, Thailand

FORSPAf Forestry Research Support Programme for Africa (proposed)

FTP Forestry Training Programme, Finland

IARC International Agricultural Research Center (in the CGIAR system)

ICRAF International Centre for Research in Agroforestry (CGIAR), Kenya

IFPRI International Food Policy Research Institute (CGIAR), Washington, D.C., USA

IFS International Foundation for Science, Sweden

IGADD Inter-Governmental Agency on Desertification and Drought, Djibouti

IITA International Institute for Tropical Agriculture (CGIAR), Nigeria

IPGRI International Plant Genetic Resources Institute (CGIAR, formerly, International Board for Plant Genetic Resources (I BPGR)), 1 taly

ISNAR International Service for National Agricultural Research (CGIAR), Netherlands

IUFRO International Union of Forestry Research Organizations, Austria

MADELEÑA Central America regional project on tree cropping and fuelwood production (ROCAPCATIE), Costa Rica

MIRA Manejo de information sobre recursos arboreos (database at CATIE), Costa Rica

MPTS multi-purpose tree species

NFRS national forestry research services

ROCAP Regional Office of the Central America Programs (US-AID), Guatemala

SPAAR Special Programme for African Agricultural Research (World Bank), USA

SPDC Special Programme for Developing Countries (IUFRO), Austria

TFAP Tropical Forestry Action Programme (coordinated by FAO)

TROPIS Tree Growth Potential Information System (CIFOR), Indonesia

US-AID United States Agency for International Development, Washington, D.C., USA 
Annex 1 - research recommended at SPDC regional planning workshops in Africa, 1986-1989

\section{NAIROBI I, 1986}

The second of the SPDC regional research planning workshops was held in Nairobi, Kenya, in January 1986 and entitled "Increasing productivity of multipurpose lands" (Carlson and Shea 1986). The workshop concentrated on the problems of the Sahelian and North Sudanian zones, and was attended by 35 participants from 15 African countries. In contrast to the preceding meeting at Kandy (Sri Lanka) in 1984, the Nairobi I workshop was organized around seven subject areas. For each area, a draft project document was commissioned from consultants. In practice, the workshop papers tended to be reviews, supplemented by outlines of project proposals (called "topics" in the workshop proceedings) for action within a programme (called a "proposal"). The seven subject areas and associated draft projects are listed in the following seven paragraphs:

Agroforestry research and development; agroforestry for the solution of food, fodder and fuel shortages. There were four sub-projects:

1. Agroforestry fodder species for arid lands; including the biology and reproduction of the family Capparaceae, the use of the genus Atriplex in arid zones, and the family Cactaceae for fodder and food production;

2. Agroforestry management for fodder in dry zones; including management of hedges to produce fodder, management of trees for fodder production, fodder productivity and quality of selected browse species, and phenology and physiology of leaf growth;

3. Agroforestry management for fuelwood and fodder production in dry zones; including the production of fuelwood and fodder by windbreaks, the production of fuelwood and fodder on saline lands, the production of fuelwood in various agroforestry systems (alley cropping, home gardens, farm woodlots, boundary trees and intercropping);

4. The impact of agroforestry on food production; including food production by woody plants, and studies on the tree-crop interface.

Research and development of techniques for natural regeneration for silvo-pastoral management of existing forest resources. This theme was treated as a single project with several lines of research: bioclimatology, techniques of inventory and photo-interpretation, methodology to estimate the volume and the productivity of a stand, stand regeneration techniques, management of stands and their productivity, stand dynamics, development of an agroforestry system based on natural regeneration, development of a pastoral system based on natural regeneration, and bush fires. In addition, five special studies were proposed for research. Management of indigenous trees and shrubs for the rehabilitation of degraded rangelands in the arid zone of northern Kenya. This proposal was essentially for the establishment of demonstrations of management possibilities, rather than research. Selection and genetic improvement of indigenous and exotic multipurpose tree species including seed collection, handling, storage and exchange. There were four sub-projects:

1. Exploration, conservation and provenance seed collection of multi-purpose woody spectes;

2. Evaluation and selection of genetic resources of multipurpose woody species;

3. Quantitative and qualitative improvement in multipurpose tree seed supplies;

4. Coordination of species and provenance selection of multipurpose woody species.

- Developing and using biolechnologies in forestry and agrolorestry in the Sahelian and SudanoSahelian zones. There were two sub-projects:

1. Selection and genetic improvement of ligneous material;

2. Biotechnology of the symbiotic micro organisms. 
Research and development of nursery practices and techniques for the establishment and management of fuelwood plantations including water harvesting and distribution. Eight sub-projects were proposed:

1. Continued training for forestry staff; including evaluation and preparation of a project document, and establishment and operation of training units;

2. Preparation of analytical bibliographies specific to dry tropical regions in the field of nurseries, plantation establishment and management, with triennial revision;

3. Directory of forestry research in dry tropical Africa, with triennial revision;

4. Directory of forestry dcvclopment in dry tropical Africa, with triennial revision;

5. Nurseries: evaluation of techniques used, dissemination of knowledge, planning of further research; including the evaluation of existing techniques and practices, distribution of technical data sheets and extension manuals, preparation of project documents, and performance of research contracts;

6. Plantations: evaluation of techniques used, dissemination of knowledge, planning of further research; including the evaluation of existing techniques and practices, distribution of technical data sheets and extension manuals, preparation of project documents, and performance of research contracts;

7. Development of a method for site description; including theoretical approach and preliminary data collection, testing of the method through a network of observation areas (a case study), appraisal and foal adjustment of the method;

8. Hardening under Sahelian conditions of gum acacias propagated by tissue culture.

Nursery and fuelwood plantation practices in arid and semi-arid zones of North-East Africa. This document did not propose any particular projects but discussed points to be considered in the preparation of projects. A checklist of topics worthy of further effort included the following ten main subjects:

1. Sociological and institutional research;

2. Choice of species and provenances;

3. Seed research;

4. Nursery research;

5. Plantation establishment;

6. Plantation management and protection;

7. Basic rhizosphere studies;

8. Tree improvement;

9. Basic economic studies;

10. Work study.

At the end of the Nairobi I workshop the participants were asked to state their level of interest in each proposed programme and the component research projects. The interest was rated subjectively as low, medium or high. Scores were tallied with respect to the replies from the representatives of the country or countries involved in a project, the donor agencies, and other participants at the workshop. Two proposed programmes received high ratings and were discussed at the Nairobi II meeting in early 1987. The other projects still await response from the donor agencies.

\section{NAIROBI II, 1987}

Two programme proposals were carried forward from the Nairobi I workshop to a second meeting in the same city in February-March 1987, entitled "Tree improvement and silvo-pastoral management of savanna woodlands in the Sahel and North Sudanian zones of Africa". The outline for the selection and genetic improvement of multipurpose trees and shrubs was of high interest to 89 per cent of the African participants and 82 per cent of the forestry advisers of the donor agencies at Nairobi I. The directors of research and the tree breeders of 14 of the 16 countries concerned met subsequently to refine the outline. The revised draft project document was presented at the meeting of the Special Programme for African Agricultural Research (SPAAR) in Paris (France) in May 1987. France agreed to fund the international coordination of this sub-regional project for an initial period of 19 months. FAO was the executive 
agency and the coordinator was based in Djibouti. Total cost of this project was estimated at US\$ 32.4 million spread over 5 years; the coordination component was costed at US\$2.6 million.

The second highly-rated proposal at Nairobi I was for research and development of techniques for natural regeneration for silvo-pastoral management of existing forest resources. The proposal was rated highly by 50 per cent of the African participants at Nairobi I, and by 70 per cent of the forestry advisers. The revised project document prepared at Nairobi II was also presented to SPAAR at Paris in May 1987. Each pilot management centre was costed at one million US dollars spread over 5 years and 10,000 hectares. Four centres were envisaged, to cover the four combinations of climatic influence (continental versus maritime) and Sahelian rainfall $(200-600 \mathrm{~mm})$ versus North Sudanian rainfall $(600-800 \mathrm{~mm})$.

The Coordinator of IUFRO's Special Programme for Developing Countries prepared a summary in November 1987 which gave the gist of the two proposals. This summary differentiated clearly between the international and national financial contributions required for each project. It was circulated to the forestry advisers of the donor agencies at the TFAP meeting in December 1987. Both proposals were reviewed by the Forestry Working Group of SPAAR in May 1988 and received technical approval. The final versions of the two documents were prepared later in 1988 and published at the end of the year (Iyamabo 1988). The FAO-executed, French-financed regional project GCP/RAF/234/FRA began implementation in the CILSS countries in early 1990.

\section{LILONGWE, 1989}

The miombo and savanna woodlands eco-region of east-central and southern Africa was covered by a regional workshop held at Lilongwe (Malawi) in 1988. Two topics were presented: (1) the rehabilitation of degraded land by tree planting, and (2) the genetic improvement of MPTS in this eco-region. Although initial responses from donor agencies appeared positive, the proposals were to a degree overtaken by the FINNIDA-funded regional planning exercise in the SADC region and the economic problems which then prevented FINNIDA from providing subsequent support.

\section{ABIDJAN, 1989}

To continue the work of IUFRO's project group P5.01 (Properties and utilization of tropical woods) in Africa, Sales (1987) prepared a proposal for a questionnaire survey of research needs on wood technology. The large number of countries in Africa and the limited time available did not allow individual visits to be undertaken. The Project Group decided after the 18th IUFRO World Congress in 1986 to restrict the survey to 18 countries. The criteria for the sample countries were given by Sales (1987). The survey took place during 1988 and the results were discussed at a project group meeting at Abidjan in Côte d'Ivoire in late 1989. 